\title{
SOINE UNDESCRIBED SYMPTOMS OF MOSAIC IN PORTO RICAN TOBACCO
}

\author{
MELVHLE T. COOK
}

In discussing the symptoms of mosaic in plants, it is necessary to take into consideration many factors, such as:- the host, the strain of virus and the environment. It is well known that the symptoms resulting from the use of a definite virus on different species within a genu's or sometimes on varieties within a species unay be different or that the host may be a symptomless carrier of the virus. It is also well known that the symptoms vary with the strain of the virus and with environmental conditions. It should also be remembered that the response of the host to the disease may vary with the age of the host and with the rate of growth and that the rate of growth depends in a great measure on the environment.

It is very generally recognized, although not emphasized in the literature that the symptoms may undergo changes with age. The symptoms of mosaic in many plants are usually well defined on the younger leaves but the chlorctic areas gradually become green with age, so that it is impossible to distinguish the patterns on the older leaves.

Unfortunately some of the workers, following the lead of Beijerinck, Koning and other early investigations have persisted in assuming that the chlorotic areas in mosaic plants were the results of a disintegration of the chloroplasts although if this were the case the chlorotic areas should become more chlorotic with age instead of lecoming green as is the case in the common mosaic of tobaceo, sugar-cane and many other plants. It has also been assumed that the ehlorotic areas increase in size as a result of the inivasion of the green areas by the virus from the chlorotic areas. Both of these ideas have been contradicted by the writer in previonts papers. In many of the mosaic diseases, the chlorotic areas gradt.ally kecome green with age, the leaf may become uniformly green and the mosaic pattern disappears. The writer has expressed the opinion as a result of the study of several mosaic diseases that the chlorotic areas are not due to desintegration of the chloroplasts but to an inhibition of their development. Later in the growth of the kaves this inhibition is overcome and the chloroplasts increase in size and number. The writer has also expressed the opinion that 
the ehlorotic areas do not increase in size as a result of the invasion of the surrounding cells by the virus but that the increase in size is a result of cell growth and division. However, my statements fave not applied to the lesion's which are characteristic of some of the virus diseases because I have had no opportunity to study them.

The tobacco mosaic of Porto Rico may be deseribed as the common type in which we find irregular green and white areas. In some cases there is the blistering or pocketing which has been described in many publications but this symptom is not prominent. In very severe cases the entire plant may be a light yellow or almost white, the leaves small, rather brittle and the margins turned down. There are several modifications of the pattern but thus far the writer has been umable to separate these types and for the present must consider them as symptom variation due to the same virus. This virus will also produce mosaic on tomatoes and pepper and when transferred back to tobaceo the symptoms are the same as on the criginal tobaceo plant from which the virus was obtained. It ean also be transferred between tomato and pepper and will give the characteristic symptoms on each. The symptoms on the tomato are a slight reduction in size of the leaves, a mottling and the reduction of some of the basal leaflets to short spurs consisting of little more than a midrib.

When tobacco plants are inoculated with a hypodermic needle, inserted at the node, the symptoms appear in from five to ten days; occasionally earlier on the very young leaves. These inoculations were made at various heights on the plants. The typical symptoms developed on the new foliage at the top of the plant and on new shoots at any point on the plant. However, it is the symptoms on the older leaves which were formed previous to inoculation to which the writer wishes to call your attention at this time.

If the mosaic is a disease of the meristematic tissue as stated by various writer in the past or to state the case from the more modern view point, if the meristem is the only tissue that responded to the influence of the virus, will symptoms be developed in the leaves in which the tissues were fully differentiated? These experiments inaicated that the typical symptoms rarely developed on the old leaves, that is the leaves that had reached their full size did not show any symptoms; and that the symptoms on leaves that were not quite full sized at time of inoculation, but in which the tissues were fully differentiated sometimes developed more or less eircular areas which are sightly lighter in color that the surrounding parts of the leaves. This was due to the inhibition of the chloroplasts. 
The effect of direct inoculation into the mesophyll of the leaves was tested by the following method.

Leaves ranging from one to two inches in length were inoculated by rubbing with cheese cloth soaked in juice from a mosaic plant. In from five to ten days circular spots about ten to twelve millimeters in diameter appeared. These spots were slightly lighter in color than the other parts of the leat. When these leaves were he!d to the light, similar areas could be detected in other parts.

The tobaceo plants of fifteen leave's each were inoculated by rubling the leaves on one side of the plant with cheese eloth soaked in juice from mosaic plants. The leaves were measured at time of inoculation and later to determine which, if any, had made their iull growth. In five days three of the inoculated leaves on one plant and four on another plant developed areas as described. Five leaves on the third plant developed symptoms in six days. This experiment was repeated several times with similar results. Symptoms were very rarely developed on the uninoculated leaves. No spots appeared on leaves that were full sized before inoculation.

A study of the histology of the leave's of different ages showeif 11) that when the tissues were not fully differentiated at time of inoculation, there was an inhibition of the development of both cell strueture and chloroplasts and that the younger the leaves the greater the inhibition; (2) that when chlorotic areas were formed on leaves in which the tissues were fully developed, there was no change in cell structure but that the development of the chloroplasts har been inhibited; (3) that the enlargement of these areas whiol cceurs on the young leaves is due to cell division and cell growth and not to an invasion of the surrounding cells by the virus. Chlorotic areas did not appear in leaves that had reached full size previous to the inoculation. 